\title{
CANE FARMERS COMMUNITY PARTNERSHIP PATTERN WITH PT. PG. GORONTALO
}

\author{
Anas Jusuf ${ }^{*}$ 1), Amir Halid ${ }^{2)}$, Muhammad Amir Arham ${ }^{3)}$ \\ 1) Department of Agribusiness Post Graduate State University of Gorontalo \\ 2) Faculty of Agriculture State University of Gorontalo \\ 3) Faculty of Economic State University of Gorontalo \\ *) Corresponding Author E-mail: jusufanas09@gmail.com
}

\begin{abstract}
The study aims to (1) Describe the perception of sugar cane farmers in the district was on a partnership with PT. PG. Gorontalo farmers; (2) Describe the factors that influence the success of the partnership program sugar cane farmers in the district was by PT. PG. Gorontalo; (3) Analyze the contribution of sugar cane farmer partnership with PT. PG. Gorontalo to the income of farmers in the district was. This research is quantitative. Sources of data in this study are primary data from questionnaires to farmers. Data analysis technique used is descriptive analysis, regression and simple regression. These results indicate that (1) The partnership pattern obtained and applied to partnerships sugar cane farmers in the district was by PT. PG. Tolangohula namely Gorontalo Province Operational Cooperation patterns Agribusiness (KOA). Farmer partnerships to provide benefits to growers of sugar cane but still less than optimal on the issue of determining the selling price of sugar cane is not appropriate and farmers' rights and obligations of the partner company of farmers not fulfilled in accordance with the terms and agreements. (2) The results of multiple regression analysis about factors that affect the success of the partnership of farmers found that internal factors, external factors, the characteristics of partnership, participation of farmers and supporting components of the partnership jointly significant effect on the success of the partnership program sugar cane growers of the people in the district was the value of the determinant of $63.30 \%$, while it partially only variable that does not pick internal factors have a significant effect. (3) Partnerships sugar cane farmers in the district was by PT. PG. Gorontalo positive and significant impact on people's income taboo sugar cane farmers in the district was the positive benefit contribution rate of 0.268 or by $26.8 \%$. This shows that the partnership is very beneficial for farmers' incomes but its implementation still need to be addressed in order to provide a greater contribution to the income of farmers folk taboo.
\end{abstract}

Keywords: Partnership; Sugar Cane Growers; Revenue

\section{INTRODUCTION}

Increased production of sugar cane needs to be addressed seriously enough to meet the demand for sugar cane to the factory, as a raw material for production of sugar. However, given the lack of capital and technology and the risk in the development of sugar cane farming then it is very necessary to have a partnership between cane farmers and sugar mills in order to increase income of farmers. With the partnership is expected to provide benefits for each party, both sugar cane farmers and sugar mills, because the sugar cane growers can obtain the appropriate tegnologi over in an effort to increase cane production. Besides sugar cane farmers also receive a guaranteed market for their production in accordance with the agreed quality and price. Price is formed is expected to provide benefits for sugar cane farmers, so that the agreed prices will ensure continuity of 
farming as well as to increase the income of farmers. In improving the good execution of the partnership it needs to be improved through partnership management, which according Badrudin (2014) resources management (tools of management) into a $6 \mathrm{M}$, namely: (1) Man (2) Money (3) Method (4) materials (5) Machines (6) Market. So with these aspects, the researcher can classify factor in sugar cane farming partnership management include internal factors, external factors, the characteristics of partnership, participation of farmers and supporting components partnerships.

The explanations related to this research is focused at Sugar Factory PT. PG. Gorontalo. As Director General of Plantations year program 2015-2019 is Increased Production and Productivity of Plantation Crop Husbandry, with its strategic objectives "Realization of increased production and productivity of plantation crops optimally and the development of bio-industry system of sustainable agriculture". Program performance indicators, especially for the rate of increase of crop production on average of $7.78 \%$, while for other plantation crops featured by $3.38 \%$. Achievement of the performance indicators of the program should be realized by the fulfillment of sugar cane raw material supply in order to increase the national sugar production.

The problem is a partnership that is applied during this time has not run optimally and yet creates manufacturing cost efficiencies for sugar cane farmers that have an impact on the availability of the factors of production required for the production costs are quite high. In another aspect of the working relationship between sugar cane farmers by sugar mill company has not gone well so the impact on social values are quite needed by the company's sugar cane farmers and sugar mills now and in the future.

\section{METHOD}

Analysis of the data in this study includes two analyzes the descriptive analysis and multiple regression analysis and simple regression.

\section{Descriptive analysis}

Calculation of a score can be obtained through the following calculation:

$$
\% \text { Skor Pernyataan }=\frac{\text { Skor Aktual }}{\text { Skor Ideal }} \times 100 \%
$$

\section{Multiple Regression Analysis}

The multiple linear regression equation of $X$ to $Y$ is defined as follows:

$$
\hat{Y}=\alpha+\beta X 1+\beta X 2+\beta X 3+\beta X 4+\beta X 5+\varepsilon
$$

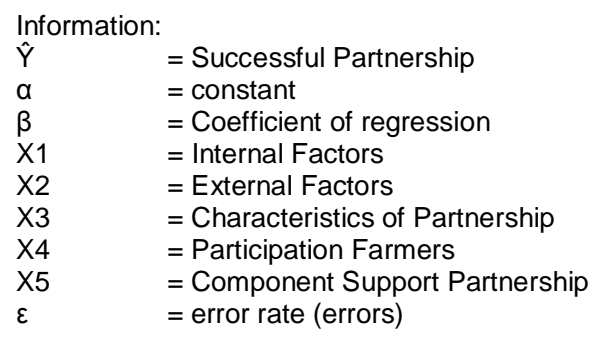

\section{Analysis of Farmers' Income}

Sugar cane farmers' income mathematically calculated using revenue analysis as follows (Soekartawi, 1995):

$$
\begin{array}{ll}
\mathrm{Y} & =\mathrm{TR}-\mathrm{TC} \\
\mathrm{TR} & =\mathrm{P} \times \mathrm{Q} \\
\mathrm{TC} & =\mathrm{TFC}+\mathrm{TVC}
\end{array}
$$




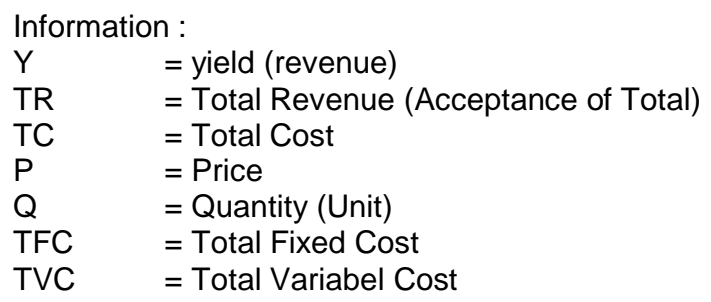

\section{Simple Regression Analysis}

The linear regression equation of $X$ to $Y$ is defined as follows:

Information:

$$
\hat{\mathrm{Y}}_{\mathrm{RT}}=\alpha+\beta X
$$

$\begin{array}{ll}\hat{\mathrm{Y}}_{\mathrm{RT}} & =\text { Revenue farmers } \\ \alpha & =\text { Constant } \\ \beta & =\text { Coefficient of regression } \\ \mathrm{X} & =\text { Partnership of farmers }\end{array}$

\section{RESULTS AND DISCUSSION}

\section{Analysis Perception Cane Farmers The district was on Partnership Farmers PT. PG. Gorontalo}

The results of the analysis of the partnership by respondents as follows:

Table 1. Partnership Between Sugar Cane Growers in the District was by PT. PG. Gorontalo

\begin{tabular}{|c|c|c|c|c|c|c|c|c|c|}
\hline \multirow[b]{2}{*}{ Statement } & \multicolumn{8}{|c|}{ SCORE STATEMENT } & \multirow{2}{*}{$\begin{array}{l}\text { CRITERIA } \\
\text { Statement }\end{array}$} \\
\hline & F1 & F2 & F3 & F4 & F5 & Currents & Ideal & $\%$ & \\
\hline $\mathrm{P} 1$ & 0 & 14 & 22 & 22 & 28 & 322 & 430 & $74.88 \%$ & Pretty good \\
\hline P2 & 0 & 7 & 16 & 44 & 19 & 333 & 430 & $77.44 \%$ & Pretty good \\
\hline P3 & 0 & 2 & 15 & 45 & 24 & 349 & 430 & $81.16 \%$ & Well \\
\hline P4 & 6 & 3 & 7 & 16 & 54 & 367 & 430 & $85.35 \%$ & Well \\
\hline P5 & 0 & 0 & 28 & 39 & 19 & 335 & 430 & $77.91 \%$ & Pretty good \\
\hline P6 & 0 & 0 & 10 & 30 & 46 & 380 & 430 & $88.37 \%$ & Well \\
\hline P7 & 4 & 6 & 17 & 24 & 35 & 338 & 430 & $78.60 \%$ & Pretty good \\
\hline P8 & 4 & 0 & 13 & 32 & 37 & 356 & 430 & $82.79 \%$ & Well \\
\hline P9 & 39 & 15 & 24 & 3 & 5 & 178 & 430 & $41.40 \%$ & Not good \\
\hline P10 & 4 & 3 & 26 & 26 & 27 & 327 & 430 & $76.05 \%$ & Pretty good \\
\hline P11 & 13 & 6 & 18 & 35 & 14 & 289 & 430 & $67.21 \%$ & Pretty good \\
\hline P12 & 0 & 4 & 12 & 39 & 31 & 355 & 430 & $82.56 \%$ & Well \\
\hline $\mathrm{P} 13$ & 0 & 0 & 12 & 28 & 46 & 378 & 430 & $87.91 \%$ & Well \\
\hline P14 & 0 & 0 & 44 & 15 & 27 & 327 & 430 & $76.05 \%$ & Pretty good \\
\hline P15 & 0 & 4 & 11 & 12 & 59 & 384 & 430 & $89.30 \%$ & Well \\
\hline P16 & 0 & 0 & 10 & 17 & 59 & 393 & 430 & $91.40 \%$ & Well \\
\hline Total & 70 & 64 & 285 & 427 & 530 & 5.411 & 6.880 & $78.65 \%$ & Pretty good \\
\hline
\end{tabular}

Based on the Table 1 it can be seen that the partnership of farmers able to benefit both farmers. The existence of a sugar mill can affect people's lives around the plant. In the presence of the sugar factory is certainly an impact on the economic life of the surrounding community. In addition, the presence of the sugar mill community culture growing province. The results are pretty good that dominates the criteria regarding the partnership is due to various factors that still less than optimal as concerning the determination of the selling price of sugar cane that is still not appropriate then the more crucial that the farmers' rights and obligations of the partner company of farmers who are not complied with and implemented in accordance with the terms and agreements.

Implementation of the partnership between PT. PG. Tolangohula Cooperative Cane Farmers and farmer groups organized under the Partnership Cooperation Agreements. The agreement contains chapters about the terms of membership, rights and obligations, 
the provision and distribution of funds and drawdown, harvest, sugar cane replacement value, sanctions, delivery of production output, the duration of the agreement, and dispute resolution. The contents of the agreement, if adhered to by companies and farmers/cooperatives, will benefit both parties. On the one hand, because the company will have secure supplies of sugar mills shoulder on the terms agreed. On the other hand, a group of farmers/cooperatives will obtain technical guidance cultivation of sugar cane, sugar cane market guarantee results according to the price agreed, and guarantee funds from the farming social aid, scroll funds, and other funds of the company. In this case, a partnership in which the partner groups (groups of farmers/cooperatives) will provide land, facilities and manpower, while the partner company (PT. PG. Tolangohula) provides a means of transportation and other expenses such as the cost of harvesting (Act No. 20 of 2008 on Business micro, Small and Medium Enterprises). On the part of farmers, the agreement with the partnership of the operations will increase revenue in order to assure a smooth and continuing partnership between farmers and companies.

\section{Analysis of Factors Influencing Success Partnership Program Against Sugar Cane Farmers in the District was by PT. PG. Gorontalo}

The results of the analysis of the management of the partnership can be seen from the results of the descriptive analysis is presented as follows:

Table 2. Descriptive Results

\begin{tabular}{clcccc}
\hline \multirow{2}{*}{ No. } & \multirow{2}{*}{ Variables } & \multicolumn{3}{c}{ variable score } & \multirow{2}{*}{ Criteria } \\
\cline { 3 - 4 } & & Currents & Ideal & $\%$ & \\
\hline 1 & The success of the Partnership Program & 1,248 & 2.064 & $60.47 \%$ & Pretty good \\
2 & Internal factors & 1,717 & 3.096 & $55.46 \%$ & Not good \\
3 & External factors & 1.432 & 2.064 & $69.38 \%$ & Pretty good \\
4 & characteristics of Partnership & 2,770 & 3.440 & $80.52 \%$ & Well \\
5 & Farmer participation & 1,810 & 2.408 & $75.17 \%$ & Pretty good \\
6 & Supporting component & 3,034 & 4,128 & $73.50 \%$ & Pretty good \\
\hline \multicolumn{2}{l}{ Source: Data Processed, 2019 } & & &
\end{tabular}

Based on the Table 2 it can be seen the results of the descriptive analysis that the characteristics of the partnership lies in a good criteria. Variable success of the partnership program, external factors, farmers' participation and support components are at criteria pretty good. Then to internal factors lies in the criteria that are less good. The results of the analysis with SPSS shown in Table 3 as follows:

Table 3. Results of Multiple Regression Analysis

\begin{tabular}{|c|c|c|c|}
\hline \multirow[t]{2}{*}{ Model } & \multicolumn{2}{|c|}{$\begin{array}{c}\text { Coefficients } \\
\text { unstandardized }\end{array}$} & \multirow{2}{*}{$\begin{array}{c}\begin{array}{c}\text { standardized } \\
\text { Coefficients }\end{array} \\
\text { beta }\end{array}$} \\
\hline & B & Std. Error & \\
\hline (Constant) & -6099 & 1,780 & \\
\hline Internal factors & .018 & .069 & .020 \\
\hline External factors & .188 & .084 & .179 \\
\hline Characteristics of Partnership & .227 & .056 & .327 \\
\hline Farmer participation & .133 & .066 & .183 \\
\hline Supporting component & .253 & .070 & .328 \\
\hline
\end{tabular}

Source: Data processed, 2019

Based on the Table 3 in the column Coefficients unstandardized, the multiple regression equation which is as follows:

$$
\hat{Y}=-6.099+0,018 X 1+0,188 X 2+0,227 X 3+0,133 X 4+0,253 X 5
$$


1) Against internal factors influence the success of the partnership program

Internal factors significant value greater than 0.05 probability value, or the value $(0.790>0.05)$, the internal factors but not significant positive effect on the success of the partnership program sugar cane farmers in the district was.

2) The influence of external factors on the success of the partnership program

External factors significance value less than 0.05 probability value, or the value $(0.027<0.05)$, the external factor positive and significant impact on the success of the partnership program sugar cane farmers in the district was.

3) Against the partnership characteristics influence the success of the partnership program

Significant value characteristics of the partnership is smaller than the probability value of 0.05 , or a value $(0.000<0.05)$, the characteristics of a partnership and a significant positive effect on the success of the partnership program sugar cane farmers in the district was.

4) Effect of farmer participation to the success of the partnership program

Farmer participation significance value less than 0.05 probability value, or the value $(0.046<0.05)$, the participation of farmers positive and significant impact on the success of the partnership program sugar cane farmers in the district was.

5) Against partnerships supporting components influence the success of the partnership program

The significant value of partnerships supporting components smaller than the probability value of 0.05 , or a value $(0.001<0.05)$, the components of the partnership supporting positive and significant impact on the success of the partnership program sugar cane farmers in the district was.

The magnitude of the coefficient of determination or number of Adjusted $\mathrm{R}$ Square of 0.633 . This value indicates that $63,30 \%$ of the variability of the success of the partnership program sugar cane farmers in the district was able to be explained by internal factors, external factors, the characteristics of partnership, participation of farmers and supporting components partnerships. While the rest of $36,7 \%$ is explained by other variables not examined in this study, such an attitude of partner companies, the ability of human resources at the company's partners and institutional optimization factor between sugar cane growers with partner companies.

\section{Analysis of Contributions Cane Farmers Partnership with PT. PG. Gorontalo Against Farmers' Income in the district was.}

Results of the analysis of the income of farmers who have partnered with PT. PG. Gorontalo are presented as follows:

Table 4. Analysis of Sugar cane Farmers' Income

\begin{tabular}{lcc}
\hline \multicolumn{1}{c}{ Item } & Information & Value \\
\hline \multirow{2}{*}{ Revenue } & $\mathrm{Kg}$ & 126.500 \\
& $\mathrm{Rp}$ & 48.070 .181 \\
& seedling & 8.142 .375 \\
\multirow{2}{*}{ Cost } & $\mathrm{TK}$ & 14.971 .222 \\
& Fertilizer & 2.636 .843 \\
& Herbicide & 584.484 \\
\hline Total & & 26.334 .924 \\
\hline Income & 21.735 .257 \\
\hline R/C Ratio & 1,86 \\
\hline Profit Margin & $41,10 \%$ \\
\hline Source: Data Processed, 2019 &
\end{tabular}

Based on the Table 4 it can be seen that the production of farmers at an average of $126500 \mathrm{~kg}$ which then produce revenues of Rp. 48,070,181. From sugar cane farming activities, farmers have to sacrifice or cost of Rp. $26,334,924$. So that the average farmer's 
income of $R p 21,735,257$. With these results it can be seen that the value of $R / C$ ratio of sugar cane farming is conducted in partnership with PT. PG. Gorontalo at 1.86 times and then with the level of profit margin of $41.10 \%$. This shows that the sugar cane farming is done by the farmer is able to contribute to the income of farmers.

Meanwhile to find out how the contribution of Sugar Cane Growers partnership with PT. PG. Gorontalo against Sugar Cane Farmers' income taboo people in the district was, and the amount of contribution to be presented through a simple regression analysis as follows:

Table 5. Simple Regression Analysis

\begin{tabular}{|c|c|c|c|c|c|c|}
\hline \multirow[t]{2}{*}{ Model } & \multicolumn{2}{|c|}{$\begin{array}{c}\text { Coefficients } \\
\text { unstandardized }\end{array}$} & \multirow{2}{*}{$\begin{array}{c}\begin{array}{c}\text { standardized } \\
\text { Coefficients }\end{array} \\
\text { beta } \\
\end{array}$} & \multirow[t]{2}{*}{$\mathbf{t}$} & \multirow[t]{2}{*}{ Sig. } & \multirow[t]{2}{*}{ R Square } \\
\hline & B & Std. Error & & & & \\
\hline (Constant) & -13469 & 9933 & & -1356 & .179 & \\
\hline $\begin{array}{l}\text { Partnership of } \\
\text { Farmers }\end{array}$ & .867 & .157 & .517 & 5,541 & .000 & .268 \\
\hline
\end{tabular}

Source: Data Processed, 2019

Based on the Table 5 can be seen in the simple regression equation $\hat{Y}=-13.469+$ $0,867 X$ then $t$ value of 5,541 with a significance level of 0.000 . So it can be said that the sugar cane growers partnership with PT. PG. Gorontalo positive and significant impact on people's income taboo sugar cane farmers in the district was the positive benefit contribution rate of 0,268 or by $26,8 \%$. This shows that the partnership provides benefits to farmers' income but its implementation still need to be addressed in order to provide a greater contribution to the income of farmers folk taboo.

\section{Perception Sugar Cane Farmers The District was on Partnership Farmers PT. PG. Gorontalo}

The partnership pattern obtained and applied to the sugar cane growers partnership with PT. PG. Gorontalo other forms in accordance with Law No. 9 of 1995 Article 27. The pattern of forms other than the above pattern is a partnership that is now growing, but not standardized, or a new pattern that will arise in the future which will come. As the pattern of Operational Cooperation Agribusiness (KOA) is a partnership in which the partner groups to provide land, facilities and manpower, while the partner companies provide a cost or capital and/or means to seek or cultivate an agricultural commodity.

Implementation of the partnership between PT. PG. Tolangohula Cooperative Cane Farmers and farmer groups organized under the Partnership Cooperation Agreements. The agreement contains chapters about the terms of membership, rights and obligations, the provision and distribution of funds and drawdown, harvest, sugar cane replacement value, sanctions, delivery of production output, the duration of the agreement, and dispute resolution. The contents of the agreement, if adhered to by companies and farmers/cooperatives, will benefit both parties. On the one hand, because the company will have secure supplies of sugar mills shoulder on the terms agreed. On the other hand, a group of farmers/cooperatives will obtain technical guidance cultivation of sugar cane, sugar cane market guarantee results according to the price agreed, and guarantee funds from the farming social aid, scroll funds, and other funds of the company. In this case, a partnership in which the partner groups (groups of farmers/cooperatives) will provide land, facilities and manpower, while the partner company (PT. PG. Tolangohula) provides a means of transportation and other expenses such as the cost of harvesting (Act No. 20 of 2008 on Business micro, Small and Medium Enterprises). On the part of farmers, the agreement with the partnership of the operations will increase revenue in order to assure a smooth and continuing partnership between farmers and companies.

The results of this analysis is in line with the statement of Pasaribu et al. (2013) argues that the implementation of the partnership between the Company plantation with oil palm farmers in Central Lampung, people became producer and the product then collected and processed by the company and become the perfect product that can be 
marketed. Partnership is still done by the farmers partner with the plantation company is going well and effectively.

1) Influential Factors of Successful Partnership Program Sugar Cane Farmers in the District was by PT. PG. Gorontalo

The test results showed that the management of farming is done in partnership with PT. PG. Gorontalo Farmers have different perceptions between the farmers and the management company. Then the multiple regression results about factors that affect the success of the partnership of farmers found that the factorinternal, external factors, the characteristics of partnership, participation of farmers and supporting components of the partnership jointly significant effect on the success of the partnership program sugar cane farmers in the district was the determinant value of $63.30 \%$. This is in accordance with the opinion of the Badrudin (2014) resources management (tools of management) into a $6 \mathrm{M}$, namely: (1) Man (2) Money (3) Method (4) Materials (5) Machines (6) Market. So with these aspects, the researcher can classify factor in sugar cane farming partnership management include internal factors, external factors, the characteristics of partnership, participation of farmers and supporting components partnerships.

While the partial results of each of these factors it was found that:

a. Internal factors

Internal factors consist of age, education, spending time farming and cosmopolitan level. Attitudes towards partnership internal factors that are in the category of the less well in this case it can be said that the internal factors in self farmers are not so optimal. It is also confirmed from the results of the regression that internal factors but not significant positive effect on the success of the partnership program sugar cane farmers in the district was. This is not maximal because of the characteristics of the farmers who menjai internal factors not yet contributed farmers because the farmers' position management partnership is very tied to the agreements contained in which the position of farmers unprofitable or low bargaining position.

This is also corroborated by the statement of Aryana et al. (2016) that the better characteristics of the farmers will be able to bring the farmer groups implementing achieve the level of success in farming. So with not the good characteristics of farmers into the internal aspects of an impact on the management of the partnership should be. This is confirmed by observations and interviews with farmers in sugar cane that farmers do not have the capacity and capability to influence the company's management policy, moreover, farmers tend to have low levels of education as well as the dependence of farmers to a large company, especially for farmers who have difficulty transporting sugar cane at the moment the harvest is done in the rainy season and still the dependence of farmers with the company for the search and mobilize labor for harvesting.

b. External factors

The results of the external factors was found that external factors such as facilities, technology and institutional has strived well in a partnership that exists and yet they still need improvement, especially the role of institutions or their institutions created by the company's rival to gain a double benefit of farmers. It is also confirmed from the results of the regression that external factors and significant positive effect on the success of the partnership program sugar cane farmers in the district was. This is in accordance with the opinion of Ikbal (2014) that the aim of the establishment of farmer groups is to improve and develop the ability of farmers and their families as the subject of the group to be more involved in the development.

c. Characteristics Factors Partnership

Characteristics of the partnership consists of program clarity, effectiveness and quality coaching facilitator. The results of the characteristics of the partnership are in the good category that shows the characteristics of a partnership or form partnerships there is good and can support higher revenue because it can create a market for farmers. It is also confirmed from the results of the regression that the characteristics of a partnership and a significant positive effect on the success of the partnership program sugar cane farmers in 
the district was. This is supported by a statement from Alam and Hermawan (2017) that basically the purpose and objective of the partnership is a "Win-Win Partnership". Awareness and mutual benefit here is not berartipara patisipan in these partnerships should have the same ability and strength.

d. Farmers Participation Factor

Farmers Participation factor consists of the scope of the partnership and involvement in the form of contributions. The results of the participation of farmers found that this variable is in the category good enough so that the participation of farmers in a partnership is very beneficial for the future so that farmers must be involved in every process and partnership meetings. It is also confirmed from the results of the regression that farmer participation and significant positive effect on the success of the partnership program sugar cane farmers in the district was. This is as according Suradisastra et al. (2009) that farmer participation is a component that can accelerate the process of contact interaction farmer charged to the stakeholders themselves, such an attitude (attitude) to institute new regulatory system, knowledge and skills, and willingness to cooperate. Besides that, some components outside stakeholders who influence the attitudes and willingness to interact, such as infrastructure and non-formal institutions of formal organization, the influence of local leaders, local political situation, and others.

e. Factors Supporting Components

Factors supporting components consist of mutual apprec, conformity, interdependence and transparency of information partnership. The test results support component partial secaar found that this aspect is in the category quite well that in this case it can be said that their pattern of partnership that exists which is further supported by various elements that such an attitude, transportation and compliance will provide benefits for the success of the partnership. It is also confirmed from the results of the regression that the supporting components partnership positive and significant impact on the success of the partnership program sugar cane farmers in the district was. This is as expressed by Hafsah in Rochdiani and Suranta (2007) that the partnership mechanisms that do will form a pattern that is similar to the pattern existing partnerships or different with the partnership that has developed in general. Problems often occur on farmers in conducting agricultural business partnership is an imbalance of the partnership approach which is done with the level of economic benefits gained, so that the benefits of farm business partnership is not as expected. To overcome this, we need the willingness of farmers and the company partners to implement a partnership and a partnership mechanism that has been agreed to achieve a common goal. Problems often occur on farmers in conducting agricultural business partnership is an imbalance of the partnership approach which is done with the level of economic benefits gained, so that the benefits of farm business partnership is not as expected. To overcome this, we need the willingness of farmers and the company partners to implement a partnership and a partnership mechanism that has been agreed to achieve a common goal. Problems often occur on farmers in conducting agricultural business partnership is an imbalance of the partnership approach which is done with the level of economic benefits gained, so that the benefits of farm business partnership is not as expected. To overcome this, we need the willingness of farmers and the company partners to implement a partnership and a partnership mechanism that has been agreed to achieve a common goal.

2) Contribution Cane Farmers partnership with PT. PG. Gorontalo Against Farmers' Income in the District was

The test results showed that the contribution of the sugar cane farming by farmers in partnership with PT. PG Gorontalo able to contribute income to the farmers. The regression results indicate that the sugar cane growers partnership with PT. PG. Gorontalo positive and significant impact on people's income taboo sugar cane farmers with positive benefit contribution rate by 0.268 or by $26.8 \%$. This shows that the partnership is very beneficial for farmers' incomes but its implementation still need to be addressed in order to provide a greater contribution to the income of farmers folk taboo. 
These results are consistent with the opinion of Utami (2015) that one way to increase production and also improve farmers' income sugar cane is to be applied system that partnership, which the company cooperates with farmers to obtain sufficient feedstock as well as on quality the good one. As in implementing this partnership farmer involved in producing sugar cane tied a sub-contract agreement with the company's core role as a buyer of production in accordance with the contract price that was promised at the beginning. In the capital and technology of farmers granted a loan (the cultivation and fertilization), but sugar cane produced must be sold keperusahaan core.

This partnership will be saving the cost components that are crucial for sugar cane farmers' income. Components cane farming costs consist of fixed costs and variable costs. Fixed costs which consist of depreciation of tools and farm machinery. The variable cost consists of the cost of seed, fertilizer, pesticide and labor costs. An analysis of revenue is generally used to evaluate the agricultural activities in the growing season toovercoming differences in production scale farmers. Revenue analysis conducted with the aim of helping to improve management of the farms. Aspects used are the prevailing prices, and depreciation accounted for in the year to gain the maximum advantage (Herman, 2009). The existence of positive income level and the $\mathrm{R} / \mathrm{C}$ ratio is greater than 1.5 times the unit and profit margins were above $40 \%$ indicates that usahtani cane by utilizing the partnership will increase the income of farmers.

The test results are in line with the statement of Utami et al. (2016) that the partnership applied in PT. PG. Regional II unit PG Jatitujuh, Majalengka which Intiplasma core pattern. It can be characterized in that the Company provides production facilities, provide technical guidance, management, sustain and manage and market their production. Cane farm income with a system of partnership schemes can increase the income of farmers. There are significant patterns of partnership developed sugar factory on revenue.

\section{CONCLUSION}

The partnership pattern obtained and applied to partnerships sugar cane farmers in the district was by PT. PG. Tolangohula namely Gorontalo Province Operational Cooperation patterns Agribusiness (KOA). Farmer partnerships to provide benefits to growers of sugar cane but still less than optimal on the issue of determining the selling price of sugar cane is not appropriate and farmers' rights and obligations of the partner company of farmers not fulfilled in accordance with the terms and agreements.

Farm management is done in partnership Sugar Cane Farmers in the district was by PT. PG. Gorontalo has a different perception between farmers and the company's management. Then the multiple regression results about factors that affect the success of the partnership of farmers found that the factor internal, external factors, the characteristics of partnership, participation of farmers and supporting components of the partnership jointly significant effect on the success of the partnership program sugar cane farmers in the district was the value of the determinant of $63.30 \%$, while it partially only variable internal factors that have no effect significant.

Sugar cane farming is done by cane farmers in the district was in partnership with PG Gorontaloable to contribute income to the farmers. The regression results indicate that the sugar cane growers partnership with PT. PG. Gorontalo positive and significant impact on people's income cane farmers in the district was the positive benefit contribution rate of 0.268 or by $26.8 \%$. This shows that the partnership is very beneficial for farmers' incomes but its implementation still need to be addressed in order to provide a greater contribution to the income of farmers folk taboo. 


\section{REFERENCES}

Alam, A. S., \& Hermawan, H. 2017. Faktor-faktor Yang Mempengaruhi Hubungan Kemitraan Antara Petani Budidaya Jamur Tiram Dengan CV. Asa Agro Corporation. AGROSCIENCE (AGSCI), 7(1), 214-219.

Aryana, A. A. N. B., Budhi, M. K., \& Yuliarmi, N. N. 2016. Pengaruh Karakteristik Petani Dan Peran Pendamping Terhadap Keberhasilan Simantri di Kabupaten Badung. EJurnal Ekonomi dan Bisnis, 5(4), 689-720.

Badrudin. 2014. Dasar-dasar Manajemen. Bandung: Alfabeta

Ikbal, Mohamad. 2014. Peranan Kelompok Tani Dalam Meningkatkan Pendapatan Petani Padi Sawah Di Desa Margamulya Kecamatan Bungku Barat Kabupaten Morowali. e-J. Agrotekbis, 2(5), 505-509.

Pasaribu, A. I., Hasanuddin, T., \& Nurmayasari, I. 2013. Pola Kemitraan Dan Pendapatan Usahatani Kelapa Sawit: Kasus Kemitraan Usahatani Kelapa Sawit Antara PT Perkebunan Nusantara VII Unit Usaha Bekri dengan Petani Mitra di Desa Tanjung Jaya, Kecamatan Bangun Rejo, Kabupaten Lampung Tengah. Jurnal IImu IImu Agribisnis: Journal of Agribusiness Science, 1(4), 358-367.

Rochdiani, D., \& Suranta, K. J. 2007. Pola Kemitraan Antara Petani Padi Dengan PT. EFarm Bisnis Indonesia Dalam Meningkatkan Pendapatan Petani

Padi. Sosiohumaniora, 9(1), 1-6.

Soekartawi, 1995. Analisis Usahatani. Universitas Indonesia (UI-Press). Jakarta

Suradisastra, K., Hastuti, E. L., Wiryono, B., Budhi, G. S., \& Tarigan, H. 2009. Perumusan Model Kelembagaan Petani Untuk Revitalisasi Kegiatan Ekonomi Pedesaan. Laporan Sinergi Penelitian Pertanian dengan Perguruan Tinggi dan LPDN dengan LPD (SINTA). Pusat Analisis Sosek dan Kebijakan Pertanian.

Utami, A., Dinar, D., \& Sumantri, K. 2016. Pengaruh Pola Kemitraan Terhadap Pendapatan Petani Tebu. Agrivet: Jurnal IImu-IImu Pertanian dan Peternakan (Journal of Agricultural Sciences and Veteriner), 4(1), 1-8.

Utami, S. 2015. Evaluasi Pola Kemitraan Usaha Tani Tebu (Studi Pada PTPN X (Persero) PG. Pesantren Baru Kediri). Jurnal Administrasi Bisnis, 20(1), 1-10. 